\title{
Short Tribute to Ben Agger
}

\author{
Elisabeth Chaves
}

I never met Ben Agger. During my first year as a doctoral student, I was introduced to his scholarship through one of his former students. His concept of "literary political economy" became a guide star for my work during the $\mathrm{PhD}$. The first article I published on the literary political economy of the then emergent trend of literary blogs found a home in his journal Fast Capitalism.[1] I was a somewhat non-traditional political and social theory student who had formerly studied law and urban planning. My previous exposure to critical theory had been one Doug Kellner article on television while an undergraduate. To say I was winging it as a first year PhD student immersed in the Frankfurt School would be an understatement. Thankfully, I had Agger's 1991 article, "Critical Theory, Poststructuralism, Postmodernism: Their Sociological Relevance," to assist me.[2] When I began to wonder how exactly academics could be critical theorists and employed, I turned to Ben and his sometimes co-author and coeditor, Tim Luke (also my dissertation advisor), as mentors and exemplars, even if their prognosis for my academic future (and those of others similarly situated) was/is somewhat bleak. [3] They provided me with an advance map of the terrain I would encounter as I negotiated the two poles of interesting, meaningful, critical work and work that a university might find "useful." Ben wrote me letters of recommendation for dissertation fellowships and post-docs that I never received. But his short bursts of encouragement - "Your project sounds fascinating" - motivated me to continue. Ben's work on the decline of discourse, the transformative changes to the public sphere and capitalism wrought by new technology and new media, and the role that academia itself played in deforming critical scholarship into measurable "journal science" or garbled non sequiturs that begged for the Sokal hoax all encouraged me to think clearly not only about the possibility for critical politics today but also about how I myself might contribute to or detract from that possibility through my scholarship. [4] Ben may not have anticipated the commodification of "fake news" and its impact on a national election, or a "public sphere" in which the President retweets a sixteen year old's criticism of $\mathrm{CNN}$ as support for his claim of voter fraud. However, his concept of literary political economy and his analysis of the decline of discourse provide strong insights into where we have arrived and how we got here. When I completed my book, a study of political criticism in journals over time, Ben eagerly accepted my request to write a blurb. [5] I owe many of the book's insights to him. It was a great honor when Ben asked me to join the editorial board of Fast Capitalism just a year and a half ago. I very much regret that I never had the opportunity to meet him or give him my sincere thanks for the role he played in my development as a scholar. Ben's work helped orient me, while his personal encouragement and support assisted me in making the transition from graduate student to colleague. He will be missed.

\section{Endnotes}

1. Elisabeth Chaves, "The War between $n+1$ and The Elegant Variation, Or When Production Overlooks Consumption in the Literary Political Economy," Fast Capitalism 4.1, available at <http://www.fastcapitalism. $\mathrm{com} />$.
2. Ben Agger, "Critical Theory, Poststructuralism, Postmodernism: Their Sociological Relevance," Annual Review of Sociology 17 (1991): 105-131.

3. See, for example, Ben Agger and Tim Luke, "Politics 
in Postmodernity: The Diaspora of Politics and the Homelessness of Political and Social Theory," Research in Political Sociology 11 (2002): 159-195.

4. See, Ben Agger, The Decline of Discourse: Reading, Writing and Resistance in Postmodern Capitalism (London/Philadelphia: The Falmer Press, 1990); "Theorizing the Decline of Discourse of the Decline of Theoretical Discourse?" in Critical Theory Now, Phillip Wexler (ed.) (London/Philadelphia: The Falmer Press, 1991), 118-144; A Critical Theory of Public Life: Knowledge, Discourse and Politics in the Age of Decline (London/Philadelphia: The Falmer Press, 1991); Public Sociology: From Social Facts to Literary Acts (Lanham, MD: Rowman and Littlefield, 2000); "Are Authors
Authored? Cultural Politics and Literary Agency in the Age of the Internet," Democracy and Nature 7:1 (2001): 183-203; The Virtual Self: A Contemporary Sociology (Boston: Blackwell, 2004); Speeding Up Fast Capitalism: Cultures Jobs, Families, Schools, Bodies (Boulder: Paradigm Publishers, 2004); "Political Sentences: Anti-Intellectualism, Obscurantism and Polymorphous Perversity," Sociological Inquiry 78:3 (2008): 423-430.

5. Elisabeth Chaves, Reviewing Political Criticism: Journals, Intellectuals, and the State (Farnham, Surrey, UK: Ashgate Publishing [now Routledge], 2015). 